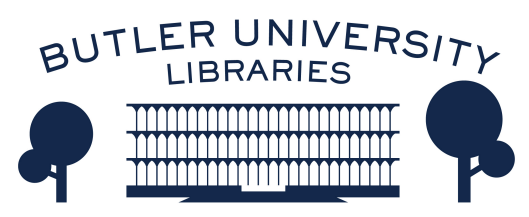

Journal of Hindu-Christian Studies

Volume 18

Article 18

January 2005

\title{
Book Review: "Divine Mother, Blessed Mother: Hindu Goddesses and the Virgin Mary"
}

Rachel Fell McDermott

Follow this and additional works at: https://digitalcommons.butler.edu/jhcs

Part of the Religion Commons

\section{Recommended Citation}

McDermott, Rachel Fell (2005) "Book Review: "Divine Mother, Blessed Mother: Hindu Goddesses and the Virgin Mary"," Journal of Hindu-Christian Studies: Vol. 18, Article 18.

Available at: https://doi.org/10.7825/2164-6279.1351

The Journal of Hindu-Christian Studies is a publication of the Society for Hindu-Christian Studies. The digital version is made available by Digital Commons @ Butler University. For questions about the Journal or the Society, please contact cbauman@butler.edu. For more information about Digital Commons @ Butler University, please contact digitalscholarship@butler.edu. 
tension between laity and clergy, articulated through festival practices and prescriptions, emerge throughout this book at nonChristian sites, as well.

In the diaspora context, Younger discusses how lay community members commonly adopt a concern for orthopraxy conventionally reserved for priests, offering a means for immigrants and their descendents to retain their roots and/or regain stability as minority members of a society. Younger moreover notes an ironic flexibility amid inflexibility within the community. On one hand, diaspora celebrations are often optional - people seem to understand if logistics make certain practices impossible. Yet, as Younger puts it, "the zeal for the faithful performance of the festival as remembered by the participants becomes a much more central factor than it would be in South India or Sri Lanka, and innovation for its own sake is clearly discouraged" (159).

In almost all instances, Playing Host to Deity demonstrates how "tradition" (contrived or true) strains against forces of entropy and innovation within the festival context. Festivals seem to offer an ideal nexus from which to view complex affiliations within participant communities and the clashing and co-mingling of deeply held desires and concerns. Younger typically allows each multi-vocal festival to speak for itself rather than providing this model of dialogue as an organizing frame; yet, in his concluding remarks about a Siva festival in
Toronto, he does equate South Indian festivals with inter-communal expression and conflict. He describes the Toronto temple community - lay and priestly, Sri Lankan and South Indian Tamil - as being enmeshed in a typical array of diaspora "debates" regarding politics, ethnicity, minority group status, aesthetics, theology, and purity of tradition. The Toronto festival, as he understands it, can only "work" when it provides a context for genuine dialogue: "Whether the [Toronto] festival will serve to contribute to those debates or act as a forum in which a few hundred people can postpone hearing those debates is a question only time will answer. If it does not contribute to those debates, it will not be a true "festival" as South India and Sri Lanka have known that phenomenon over the centuries" (158).

Superficially speaking, festivals are all about pageantry and pomp. Yet in Younger's intricate investigation we find glitz and glamour upstaged by far more urgent and wide-ranging performances. I highly recommend Playing Host to Deity to. scholars and students (of all levels) interested in exploring intersections between religious traditions and between ritual, folklore, history, and politics in South Asia and beyond.

Corinne Dempsey

University of Wisconsin at Stevens

Point

\section{Divine Mother, Blessed Mother: Hindu Goddesses and the Virgin Mary. Francis X. Clooney, S.J. New York: Oxford University Press, $2005, x i v+264$ pp.}

\begin{abstract}
DIVINE Mother, Blessed Mother is dazzling, one of the most rewarding books I have read in a long time. It offers several felicitous combinations: three Hindu goddesses and three visions of Mary; a methodological mix of textual reading, theological comparison, and personal
\end{abstract}

invitation; and a collection of texts and commentaries in Sanskrit, Tamil, Latin and Greek, all of which Clooney has beautifully translated for the first time or afresh. Arising out of what he feels to be a twentyfirst century need for Christians to reconsider gender and the divine in light of 
Hindu theology and practice, Clooney intends his book "to chart a path back and forth between being a Christian and encountering the faith and cult of goddess traditions" (viii).

His method is to read three pairs of texts, each featuring a Hindu goddess and Mary: (1) Parasara Bhattar's Sri Guna Ratna Kosa, a twelfth-century Sanskrit hymn focused on Sri, followed by the Akathistos hymn of the Patristic Greek Church; (2) "Sankara"s Saundarya Lahari, a tenth-century Sanskrit hymn to Devi, consort of Siva, paired with the medieval Latin Stabat Mater; and (3) Apirami Bhattar's Apirami Antati, an eighteenthcentury Tamil hymn to the Saiva goddess Apirami, read with the nineteenth-century Tamil Mataracamman Antati. Divine Mother, Blessed Mother is not, however, a collection of parallel goddess-Mary treatments; it focuses primarily on Sri, Devi, and Apirami, whom Mary aids us in approaching, not the reverse.

Clooney draws a lesson from each of his Hindu texts. The Sri Guna Ratna Kosa demonstrates that conventional feminine characteristics, even if stereotyped, can be re-imagined to establish the status of the goddess as second to none: as a dutiful wife, Sri may not act on her own, but Visnu does nothing without Her. By contrast, although Devi is the source of Siva's desire and desirability, the Saundarya Lahari is less interested in harmonizing Devi with Siva than with describing the goddess's beauty in such a way that people want to interact with her. "The hymn's core challenge is to show that the most efficacious means to union with Devi occurs through the ostensibly conventional practice of viewing Her loveliness" (164). The third Hindu text, the Apirami Antati, is centered on Apirami, "the lovely one," a form of Siva's consort still worshipped in the Tirukkataiyur Temple in Mylapore. The hymn is claimed by the tradition as the expression of Apirami Bhattar's Tantric visualization of the goddess's entire body. For him, experiencing her beauty is the same as experiencing her divinity.
While the Marian encounter does not replicate the three Hindu encounters, it "does approximate, as nearly as may be possible in the Christian tradition, what such encounters might possibly mean" (20). Indeed, Mary is "in her own way God's best work, ...the most luminously beautiful person we can ever see" (229), the "only one about whom one has to be reminded, "She is not divine" (148). This pulling back and denying the tendency to want to honor her as if she were a goddess saves a place in the Christian tradition for the "otherwise excluded idea of a divine woman" (17).

For those of us not as familiar as Clooney with the Marian tradition, the comparison with Mary makes us appreciate her more, and then the Hindu goddesses anew, in light of her. In addition, we read Marian devotional hymns we might otherwise miss. Particularly rich is the Tamil Mataracamman Antati, a fascinating example of the degree to which Mary has been Indianized by her Mylapore context. She is thoroughly identified with a specific Tamil place; swarming bees buzz around her beautiful feet; -she calms the struggle of craving; and she rescues local people from local dangers.

It's true:

our mother flourishes in Mylapore town where standards wave in the breeze amid paddy rich in conches and eels; her eyes are bees, her hands lotuses, her mouth a kumutam flower, this young woman:

venerate her and

the assembly of heaven-dwellers will bring you a radiant crown (91)

There are three principal morals to be taken from this wonderful book. The first is the profitability of the sort of backand-forth reading that Clooney has modeled for us here: "The particularity of this study... should make it more fruitful to discuss the merits and disadvantages of the 'option for goddesses' and 'the option for 
Mary' in feminist theological discourse" (ix).

The second is in response to contemporary feminist critiques of the religious objectification of women's bodies and of stereotyped gender roles. All three Hindu hymns claim that vision, or gazing upon the goddesses' beauty, both highlights the distinctive nature of the goddesses' power and 'transforms the viewer; physicality, pleasure, and beauty can be affirmed as spiritually significant. While he is careful to caution that there is no evidence that these Hindu texts were ever used as liberative for human women, "classic goddess texts, even in Sanskrit and by male authors, can be read to good purpose" (13).

The third lesson is the most personal. Clooney invites his readers to think of the goddesses in the Hindu hymns and Mary in the Christian ones as real persons; to become "implicated" and "entangled" in the hymns (23); to share in the state of mind of their authors; and eventually to pray. "The hymns can be used in prayer, and I hope that readers will at least think about what it would mean to use them that way" (x). With translations as beautiful as these, one is indeed moved to "wait with our eyes open for Her arrival" (237):

You are the Lord's left half,

so may the loveliness in which both of You delight

and Your auspicious wedding design too come and end the waywardness of my mind, may Your shining feet rule me, and when fierce death comes, may You stand forth (from the Apirami Antati, 72)

Rachel Fell McDermott Barnard College

\section{The Graceful Guru: Hindu Female Gurus in India and the United States. Edited by Karen Pechilis . Oxford: Oxford University Press, 2004, xi + 260 pp.}

IT is a rare pleasure to be treated to a whole book on Hindu female gurus, and this one lives up to the standards one would expect from its fine editor, range of contributors, and publisher. The mandate of the book is to explore "how Hindu female gurus respond to social expectations of femininity and how they are understood to embody the divine; how these two modes intersect in the personae of the gurus; and how their leadership is constituted by the negotiation of the two in distinctive ways" (p. 4). The nine principal chapters acquaint us with ten different guru figures - Sita Devi (Rebecca J. Manring), Gauri Ma (Carol S. Anderson), Anandamayi Ma (Lisa Lassell Hallstrom), Jayashri Ma (June McDaniel), Mother Meera (Catherine Cornille), Ma Jaya Sati Bhagavati and Karunamayi Ma (Vasudha Narayanan), Shree Ma of Kamakkhya
(Loriliai Biernacki), Ammachi (Selva J. Raj), and Gurumayi (Karen Pechilis) - and these discussions are framed by an excellent introduction by Karen Pechilis and a thought-provoking Afterword by Kathleen M. Erndl. Three of the gurus (Sita Devi, Gauri $\mathrm{Ma}$, and Anandamayi $\mathrm{Ma}$ ) are deceased and lived their entire lives in India; one (Jayashri Ma) currently lives in India; three (Karunamayi $\mathrm{Ma}$, Ammachi, and Gurumayi) travel back and forth between ashramas in India and the West; and three (Ma Jaya Sati Bhagavati, Mother Meera, and Shree Ma of Kamakkhya) have made their permanent homes in the West. Regarding - the last two categories, Pechilis describes Hindu female gurus as a "third wave" of gurus to come to the West, after Swami Vivekananda and Yogananda Paramahamsa, and the gurus of the 1960s and 1970s, like 